\title{
Secured, not connected: South Africa's Adult Education system
}

\section{John Aitchison}

Emeritus Professor, University of KwaZulu-Natal, Durban, South Africa

aitchisonjjw@gmail.com

https://orcid.org/0000-0001-5226-7709

\section{Sandra Jane Land}

Adult and Community Education Unit, School of Education, Durban University of Technology,

Pietermaritzburg, South Africa

SandraL@dut.ac.za

https://orcid.org/0000-0002-1776-079X

\section{Abstract}

In this paper we address an area that has been largely neglected by researchers-state provision of adult education in South Africa. We argue that there have been decades of neglect, or, at best, token support for our country's adult education system, and we look at how the system could be revitalised, both in terms of minimal requirements for immediate basic improvement as well as for a more radical and forward looking transformation of the system.

South Africa has a history of attempts to provide school equivalent education to black adults through night schools. Suppressed in the 1950s and 1960s, they resurfaced after the 1976 Soweto revolt, and in 1996 the Constitution secured adult basic education as a right. State night schools were renamed Public Adult Learning Centres (PALCs), and seemed poised to become a powerful delivery mechanism, but continued as inadequate night schools. In 2015 the PALC system was ostensibly transformed into a community college one, but this transformation was based on the weak foundation of inadequate PALCs. A new 2019 plan for the Community Education and Training College System includes long needed major overhauls that must be made if adults' right to effective and relevant education is to be finally realised.

Keywords: adult education; community education; community colleges; Public Adult Learning Centres. 


\section{Introduction}

Just as we suffer the frustration of a computer signalling that it has secured a link to a network, but is still not connected to the internet, we see the current state of South African adult education as secured, in terms of the Constitution's guarantee of adults' right to education, but not connected in its perennial lack of access to the full education services that would advance adult learners' knowledge and their life chances. In this paper we review the history of adult education in this country as we look forward with cautious hope to the new possibilities intimated in the incipient Community College system for adult education. We draw on document analysis, direct observation, and data we collected in our work as researchers of adult education at the University of KwaZulu-Natal (formerly University of Natal) and at the Durban University of Technology.

In the 1950s and early 1960s the apartheid state forced the closure of church, municipal, Nongovernment Organisations (NGOs), and independent night schools serving black people.

State run night schools, called Adult Education Centres or Adult Learning Centres or, more recently, Public Adult Learning Centres (PALCs), started up again in 1977 after the Soweto revolt of 1976. These new state centres were run through 13 of the various late apartheid era education departments, then through the nine post-apartheid provincial education departments, until, finally, they became the legal responsibility of the Department of Higher Education in 2009 and operationally so in 2015. They had gained some measure of legal identity with the Adult Basic Education and Training Act of 2000, but with the abolition of the Act in 2013 and in terms of the Further Education and Training College Amendment Act of 2013, they were (by legal fiat on 1 April 2015) nominally merged into nine Community Colleges (geographically one per province) and remain, in practice, unchanged as substructures of those new bodies.

Since this Community College system is being piloted, we need to look at the history of the PALCs for we cannot answer the questions "What are we?" and "Where are we going?" in respect of basic adult education unless we can answer the one that asks, "Where do we come from?" We stay cautioned about the importance of this by George Santayana's maxim, "Those who cannot remember the past are condemned to repeat it" (1905, p. 284), together with Marx's "History repeats itself, first as tragedy, then as farce" (1852, n.p.).

\section{Adult education in South Africa from 1959-2019: Snapshots and comments}

\section{Nearly 60 years ago}

The first author of this article, John Aitchison, then a student at the then University of Natal, and subsequently a director of the Centre for Adult Education there, recalls,

It is 1962 in Pietermaritzburg. Students from the University of Natal run an illegal night school in a local community hall. It continued because the municipal official in 
charge of Bantu Administration turned a blind eye towards the illegality (I honour you, Mr Bang) and one of the clerks in the local Bantu Education Department always tipped us off when the police got interested, and "lost" letters from Pretoria instructing that it be closed down (I honour you, Mr Nxumalo). I taught Biology. At that time, unbelievable as it sounds, there were no schools anywhere in the Pietermaritzburg municipality where a black person could study up to Senior Certificate level. Most of the 60 or so students were mature adults in employment (in fact, to be accepted for the examination as a part-time student one had to be employed). There were only one or two young people. Some 19 years later the once night school still survived, having, since 1963, sought refuge on the university campus, but by then was made up entirely of young matric dropouts and failures. In 1982 the university ordered it closed since it had become, in effect, a day-school for the university.

\section{Forty years ago}

Post the 1976 Soweto revolt, the Department of Education and Training (which served blacks in so-called white areas) and what was known as the homeland governments opened state night schools. They tended initially to target schoolteachers upgrading their qualifications but ran classes from literacy to Senior Certificate (matric) level. In some areas, like, for example, the Ciskei, they actually started delivering with some degree of efficiency. We had the beginnings of a state system of adult education centres delivering formal school equivalency instruction. Course materials were produced for students at all levels.

\section{In the last 25 years: Statistics in the PALC era}

By 1994 there were estimated to be 1,440 public adult education centres (PALCs) in South Africa. Centres were categorised as public, state-aided, private, and satellite (the latter not being recognised as exam centres; Harley et al., 1996). Subsequent estimates of the number of PALCs (with or without their satellite centres) vary wildly.

A University of Natal study in 1998/99 (Aitchison et al., 2000) found 3,073 PALCs, made up of 1,483 centres with their satellites and state-aided centres in eight provinces (there was no data for Limpopo). Researchers noted extreme difficulty in gaining reliable information about the number of centres, in spite of there being senior personnel in most provinces responsible for oversight and inspection of all the schools and public adult learning centres based in them.

The Human Sciences Research Council (2000) count in 1999 found 2,226, of which 2,023 catered for Adult Basic Education and Training (ABET; equivalent to school Grades 1 to 9). The national Department of Education (DoE; 2003) stated that in 2001 there were 2,494. In 2004, the DoE gave a figure of 1,895 for 2002, which distinguished between Adult Basic Education and Training (ABET) and Further Education and Training (FET; the high school equivalent) centres (Department of Education, 2004). The 2010 master list of the Department of Higher Education and Training (DHET) noted 3,083 PALCs. The 2012 Annual Survey of Adult Education Centres found 2,457 (DHET, 2014), but DHET claimed that there were 
actually 3,150 centres since a further 693 centres had not responded to the survey questionnaire sent to them! In 2016, DHET stated that there were 2,778 (DHET, 2018, p. 56).

When it comes to the number of learners, provincial data since the mid-1990s suggests that learner attendance ranged from slightly over a quarter of a million in 1995 (258,967; DoE, 1997b), up to 386,098 for $1996 / 97$, from which date there has been a steady decline from 361,385 for 1997/1998 (Aitchison et al., 2000), to 306,378 in 2012 (DHET, 2014), to 275,268 for 2014 (DHET, 2018), and to only 258,199 in 2017 (DHET, 2019).

For the period 2000 to 2013 the Auditor-General (2014, p. 11) provided an interesting graph for PALC student enrolments showing a downward trend.

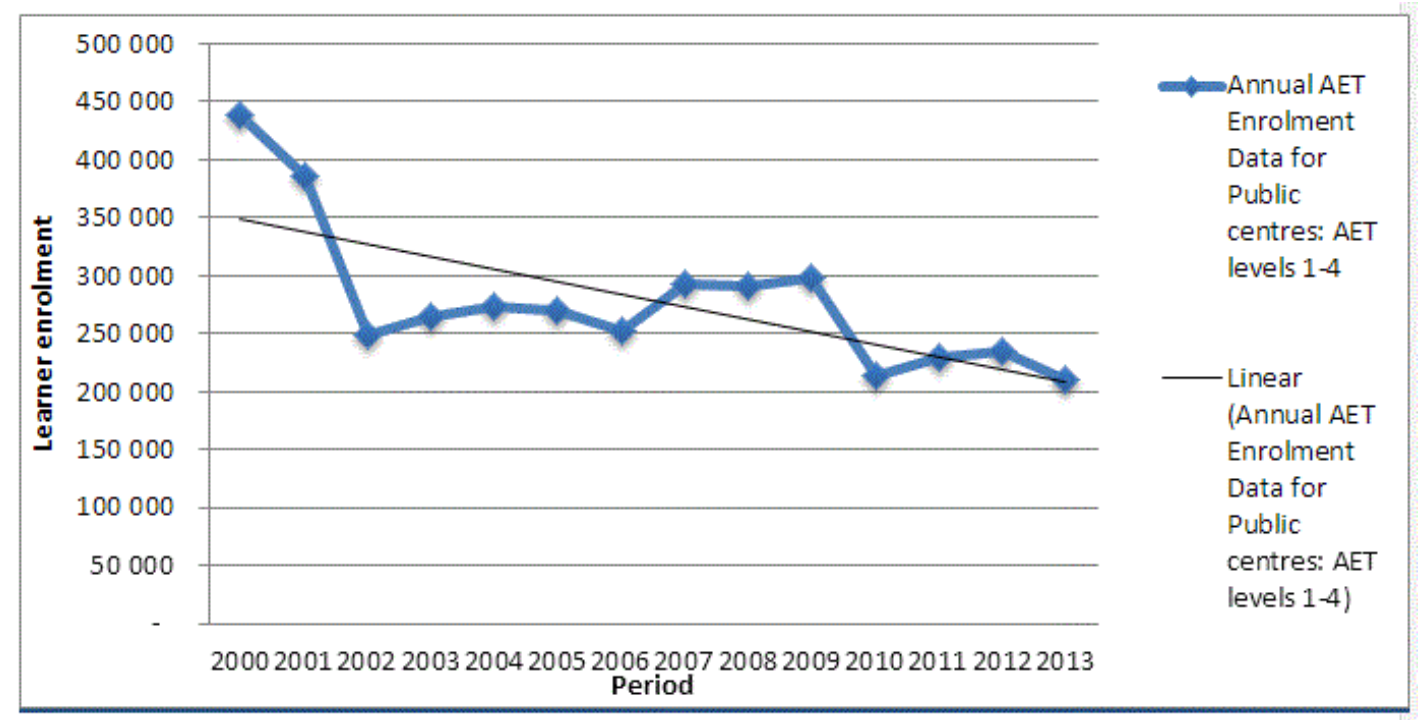

Figure 1: Annual ABET learner enrolment Level 1 to 4, 2000 to 2013

Source: Education Statistics in South Africa at a glance reports 2000 to 2009 and Education Management Information Systems EMIS) data 2010 to 2013 (DHET, 2017a)

Note: enrolment numbers reflected in the Stats at a Glance include Grade 1012 learners. AET/ABET Levels 1-4) enrolment could not be provided separately for 2000-2009

Many of the problems in the PALC statistics since the mid-1990s have stemmed from the chronic failure (or refusal) to distinguish between ABET (equivalent to National Qualifications Framework (NQF) Level 1 primary schooling) learners and FET (equivalent to NQF Levels 2 to 4 high school) learners (see DoE 2000, 2001). For virtually the whole period it was difficult to establish how many learners were at ABET level or FET level and it is likely that for many years FET learners have been either seriously under-enumerated or misclassified as ABET learners. Both the apparent official statistics and the research statistics concur in claiming something under 200,000 ABET learners.

Although the PALC system was supposed to offer adults more attractive learning options than the night schools that preceded it, it did not grow to any great extent, and, indeed, has been on a downward trajectory. Although obtaining accurate statistics about the number of ABET learners during the era of PALCs was extremely difficult (Aitchison, 2016; Aitchison \& Harley, 2006; Harley et al., 1996), it is clear that this decline was uneven across provinces, 
with Gauteng and the Western Cape, which had the most effective provincial management, suffering the least. Sadly, the decline in enrolment was not averted by the Kha Ri Gude (Let Us Learn) adult literacy campaign that enrolled over 4 million learners between 2008 and 2017 and issued most of them with an ABET Level 1 (Grades 1 to 3 equivalent) certificate (DHET, 2017a. Although it was hoped that adults who had benefited from Kha Ri Gude would enrol in ABET Level 2 at PALCs, there are no signs that the campaign made any impact at all in increasing enrolment in Level 2 or higher level classes in PALCs; these learners simply did not go on to the PALCs. The context of the Kha Ri Gude adult literacy campaign is that it was proposed by the then Minister of Education in 2006, launched officially in 2008, and ended in 2016/17. Initially, it was a well-run and successful operation that, on the whole, delivered on its programme of very basic alphabetisation (DHET, 2017a). However, the Ministerial Committee on Literacy that had planned the campaign had warned that

even the best literacy grounding is unlikely to be sustained unless followed by further exercise of these newly gained competencies. This requires that some form of postliteracy/adult basic education be available, and the Committee concurs with the Minister of Education's call for a revamping of the ABET system to make it more useful to adult learners. Evidence from Latin America strongly supports this need to have an effective post-literacy programme in place as soon as possible. (The Ministerial Committee on Literacy, 2007, p. 14)

\section{Four years ago: 2015 Magical transformation time}

At the magical hour of midnight on the 31 March 2015, the PALCs were transformed, like a host of Cinderellas, each and every one, into a community college, and before the hour had finished striking, merged into only nine community colleges, one per province. Back in the townships and rural areas, each PALC greeted the light of April Fool's Day, like Cinderella did the morning after the ball, exactly as they had been before.

A field visit in late 2015 by members of a Ministerial Committee on the review of the funding frameworks of Technical and Vocational Education and Training Colleges and Community Education and Training colleges to a selection of the supposedly better exPALCs in each province found very low enrolment in ABET 1 and 2, and heard that this was because learners with very low literacy skills were attending classes run by the Kha Ri Gude campaign. However, there was no influx of Kha Ri Gude graduates into Level 2, and enrolment was not high in ABET 3. The committee found that it was ABET 4, which leads to the General Education and Training Certificate (GETC) examination (equivalent to Grade 9), that was best attended, and that centres that ran the Amended Senior Certificate (for adults over 21 who have a GETC or other NQF Level 1 qualification or incomplete Senior Certificate) were growing. At all these centres the learners tended to be in their late teens and twenties. The Ministerial Committee also found these learning centres to be inadequate in a number of vital aspects: 
- First, most host schools provided only the barest minimum by way of facilities like simply, the use of a few classrooms after school hours. Very few PALCs had an office or place to store things. Most had no budget to pay for any utilities, water, light, or cleaning and maintenance and relied on the host school to provide these. While in a few sites, enterprising school principals found ways to share their thin resources with their PALC tenants, these host schools were themselves usually struggling to make ends meet and could not be blamed for the poor resourcing of PALCs.

- Second, staff at all centres complained about the conditions of service: most were on temporary year-by-year contracts so not eligible for any benefits even if they had been in service for more than a decade. They were not eligible for bursaries for further study to improve their qualifications for the same reason, and because they were not mainstream schoolteachers. There was a cap on how many hours they could teach a week, which varied between provinces, in spite of all being under the central control of the DHET, and when some taught extra hours they did so for no pay. Because of the poor conditions of service and their perception that adult education was, as a government priority, neglected and dying, the educators generally wanted to get into mainstream school teaching.

- Third, the situation with materials can only be described as scandalous. Some centres had no materials at all, neither textbooks for teachers to use, nor textbooks or workbooks for the learners. At some centres there was one copy of a textbook provided for a few subjects. Where there were textbooks for learners, they were totally insufficient and had to be shared among several learners (and hence were used only in class). Most of the textbooks were dated and why the Department of Education bought the particular ones they did is difficult to understand. Where textbooks were provided, they were mainly at ABET Level 4. Ironically, three excellent ABET Level 2 learner books published by the national DoE (they were prepared in 2008 by the Kha Ri Gude materials design staff) did not seem to be available. Most commercial publishers of ABET course materials had stopped producing materials because there were so few sales. No readers were provided in any of the centres. It is alarming that these learners were expected to learn to read with literally nothing provided for them to read. Disappointingly, a number of NGOs and university-based units that produced readers for ABET, and who could have supplied appropriate books with locally based content to PALCs had closed down because their books were not bought by state Departments. There was no provision of Senior Certificate materials at all. Educators had to get old out-of-date books from schools. Learners borrowed prescribed literature from school children. In the past, small quantities of exercise books were sometimes provided. At some sites some printing paper was provided. There was no practical equipment for subjects such as ancillary health care. None of the centres visited offered skills training, though learners generally wanted this. Not a single centre had computers for student use.

- Finally, a serious strain was put on centres by the demands of Umalusi Council for Quality Assurance in General and Further Education and Training, which seemed to be modelled on those that are used for conventional schools and are simply unrealistic 
(the Centre is meant to have a safe, for example) and onerous on part-time, after-hours educators, who are, with the function shift to full control by the DHET, no longer paid for invigilating and moderating. The effort required for site-based assessment and sending in portfolios was immense, and costly for learners.

\section{Links with policy}

In South Africa in the 1990s, a discourse about adult basic education (ABE), and then ABET, replaced the 1980s discourse of non-formal education in which the term literacy was dominant. The Universities of Natal and Cape Town were responsible for some of the earliest encouragement of the concept of $\mathrm{ABE}$, and this new discourse dominated the next two decades (see Aitchison, 2003a, 2003b, 2004, 2013; Aitchison \& Harley, 2006; Harley et al., 1996; Aitchison et al., 2000). Along with parallel policy changes (DoE, 1997a, 1997b), this discourse influenced PALC programmes, qualifications, curriculum, and materials. More recently, the acronym AET has been used by officialdom, with the word basic omitted from ABET.

Prior to the mid-1990s the state system was immune to discourse shifts. The DET and its homeland relatives ran courses at literacy, primary, and secondary levels and provided materials for these. The curriculum was modelled on the conventional, syllabus-based school one. However, with the political transition of the early 1990s and the desire for a large-scale adult education initiative to undo decades of exclusion and discrimination, there was a major policy shift that valorised both $\mathrm{ABE}$ and Outcomes-based Education (OBE).

Another stimulus for change came from Congress of South African Trade Unions (COSATU), who took the issue of ABE to heart in the late 1980s as part of its vision. It pushed for reforming industrial training, and for enabling workers, deprived through discrimination of the requisite education and certification, to benefit from their experientially developed skills. COSATU was wedded to the idea of general education being provided to workers alongside generic forms of skills training with portable certification. Both these issues were strongly present in reports from a National Training Board investigation (National Training Board, 1991, 1994) into a new system of industrial training for South Africa. From 1991 to 1994, the National Training Board, through eight committees representative of the state, business, labour, and service providers, worked, inter alia, on a qualifications framework, and on adult basic education. This alliance played a significant role in the policy direction that ABE took in South Africa in stressing the link between education and training, and OBE.

One of the main reasons that policy makers in the early 1990s saw the future of ABET as lying in the DoE rather than in the workplace was the existence of a functioning night school system that used the existing infrastructure of the schooling system (National Education Policy Investigation, 1992). (This is, of course, still very much the case, and school buildings and schoolteachers working part-time after school hours are the major state resource for ABET). The attempt to construct a new functional ABET system was backed by the new 
constitution's making basic adult education a right but building the new system on top of the old one was not a great success. The new national DoE's attempts at initiating nationally coordinated programmes or campaigns were mainly fiascos. The new national ABET directorate, which was understaffed and had only a small budget, tended to engage repeatedly in last minute attempts to start great leaps forward without plans or budgets, with predictable consequences of varying degrees of failure, as witnessed with the April 1995 "strategic thrusts," the 1996 Ten Thousand Learner Units, the 1997 Ithuteng campaign, the 1997 MultiYear Implementation Plan for Adult Education and Training (Aitchison, 2003a, p. 152). The latter was planned in great detail, but it was essentially an unfunded mandate to all sectors to implement, but without resources.

Despite the political prominence that accrued to adult basic education as a result of the developments described above, the overall amount of money given to state adult education hardly grew and remained a miniscule proportion (usually less than 1\%) of the provincial and the national education budgets. The upshot of all this was that what had been intended as a vibrant amalgam of basic education and training was reduced to a continuation of the previous state night school/adult education centre system offering only formal school equivalency courses of very low quality.

Two other developments interacted to further disable the state system. These were the conflation of the figures of actual ABET learners with FET learners, and the rise of OBE. First, because the discourse was about adult basic education, policies, regulations, and, in due course, legislation and the departments involved, confined themselves to adult basic education (that is, primary schooling equivalence). Although the previous night schools had also been teaching candidates for the Senior Certificate (the so-called matric) examinations, and this continued, it was never acknowledged. From 1995 onwards the prioritisation of ABET led to many provincial ABET sub-directorates not seeing FET in the PALCs as their responsibility. Plans were made to phase it out, although in reality many provinces had nearly as many FET students as ABET ones (Aitchison et al., 2000) A dire consequence of this is that education statistics continually added high school level learners to the supposed ABET participant numbers (see Aitchison \& Harley, 2006) and for virtually the entire period to date the reported statistics on the adult education system are misleading. Indeed, little reliance can be placed on any Department of Education statistics for ABET at all (see Aitchison \& Harley, 2006).

Second, the rise of OBE, with the standards apparatus of the new NQF, resulted in ABET being a major pilot of this new approach with devastating side effects. Representatives from Business South Africa and COSATU exercised a powerful influence on the adoption of the OBE approach, the former partly because commercial training providers wanted early warning of what the curriculum would be for ABET so that they could get into the field first. The fruit of their work was the National Adult Basic Education and Training Framework: Interim Guidelines of September 1995. It was a ponderous mix of transformatory rhetoric and dense rules about standards, ABET levels, level descriptors, fields of study, assessment, and language rules. It was de facto unusable, though frequently referred to. 
With the imposition of this OBE in the late 1990s there was some attempt to provide training in this approach, as well as the development of some materials (both usually designed by contracted NGOs). But a curriculum vacuum was the inevitable consequence of the policy insistence that in terms of OBE (DoE, 1997a, [Section 5.5 Qualifications]) no core curriculum or syllabus was provided by the DoE for the ABET learning areas or the broader organising fields. This was an important change from past practice where syllabi and national core curriculum guidelines laid down what should be taught and how it should be taught. In an outcomes-based approach the focus is on the outcomes of learning. How educators enabled their learners to reach these outcomes, and by what particular curriculum, was open and flexible, and educators were simply left to their own devices. This wholesale adoption of OBE, with totally inadequate budgets and teacher training, helped lead to the demise of any serious attempt to provide materials. It was blindly assumed that South African educators could interpret the meaning of the unit standards, develop their own lesson plans, and produce contextually relevant materials, despite the fact that they had never had any training nor had they been given any support to help them do this. Allied to the OBE approach was a tendency of the national directorate to have the ABET provision (although it was based on its own unit standards) conform to the schooling system's Curriculum 2005, which was itself heading on its own disastrous trajectory.

The reality of the state PALC system was that it piggybacked on school facilities after hours and relied almost exclusively on part-time staff made up of some schoolteachers working after hours, and other unqualified people scraping an income from this work. Most were not adult educators and there was little if any training offered them; only some received the twoday so-called orientation offered to schoolteachers taking on the task of teaching in PALCs (Harley et al., 1996). It was therefore unsurprising that with no actual curriculum or syllabus, these teachers failed to demonstrate the capacity they were assumed to have of being able to design a path that would be followed to reach the specified outcomes. There was no real attempt to supply materials, and what were provided were purchased in an incoherent manner in inadequate quantities by provincial education departments. Considering that the PIRLS 2016 study offers solid evidence that by the end of Grade 4, some 78\% of children in South African schools cannot read with understanding in any language (Howie et al., 2017) despite being taught by fully qualified teachers, to expect any success from the adult education system under the circumstances described above was naivety at its most extreme.

\section{Goodbye to skills training}

In spite of much rhetoric about the training part of Adult Basic Education and Training (ABET) there do not seem to be many examples of serious attempts to link ABE with training in the state system, though there were plans in the late 1990s to develop ABET electives in agriculture and small business development (Aitchison et al., 2000). In many cases the actual curriculum of these two electives was perceived by learners to be irrelevant to their needs, which may explain the recent popularity of two other electives courses, ancillary health care and early childhood development, because they offer some hope of employment as health workers or as assistants in early childhood centres and crèches. 


\section{Coming to the present}

In spite of the gradual fading away of OBE, few further developments in curriculum happened. Generally, neither the provincial education departments nor the now DHET expended much energy in relation to adult education qualifications, programmes, the improvement of teaching approaches and methods, nor to the development and distribution of materials for educators and learners. It has taken an inordinate amount of time to get approval for qualifications and curriculum proposals for adults. These include the General Education and Training Certificate for Adults (GETCA), due to replace the General Education and Training Certificate: Adult Basic Education and Training (GETC: ABET) in 2023, and the National Senior Certificate for Adults (NASCA), which is supposedly to be implemented in 2021 (DHET, 2019a). For some time, the old Senior Certificate (NATED 550) was used although this was eventually replaced by the 'Amended' Senior Certificate).

In the mid to late 1990s there was some attempt to provide some guidance on assessment in the ABET field, much of it initially influenced by the Independent Examinations Board (IEB) which developed competency-based approach ABET examinations and piloted the first of them at Level 3 in July 1994. Gradually the key position that the IEB had held was eroded, and the provincial departments started to run their own examinations until the centrally examined GETC: ABET came into operation in 2001. A fair degree of documentation was developed for the running of this examination on the basis of national policy.

Well, what happened in the new national ABET Level 4 examinations run through the provincial education departments at public adult learning centres from 2001 to date? What kind of throughput was there?

The first 2001 examination results were not auspicious; some 33,025 candidates entered and, of them, only 18,438 wrote and a mere 78 qualified for the GETC: ABET certificate (though many did gain some credits for individual learning area courses passed). Results in subsequent years are hard to assess because the DHET has year by year retrospectively adjusted the figures (generally the numbers of learners who are supposed to have been examined rises). The DHET statistics for the years 2011 to 2016 show a yearly average of 113,043 candidates registering for the ABET Level 4 examinations, 70,056 writing (62\%) and 26,323 completing (38\% of those writing, $23 \%$ of those registering; DHET, 2018). It remains a somewhat inefficient system.

As to the PALC Senior Certificate results, there is never any official release of these by Umalusi in strange contrast to the hullabaloo each year at the release of the National Senior Certificate results from schools. Neither the DBE (who set these exams) nor the DHET mention these results. We suspect there are two reasons for this secrecy: the results are devastatingly bad, for instance in 2013 of those writing six subjects, only $2 \%$ of those who entered passed; and it may be that the true picture of who enrols for this examination is deliberately not publicised (there is much anecdotal evidence of school principals forcing weak school students into doing these PALC examinations rather than the school ones). 


\section{Self-judgement}

In summing up the state of readiness of the PALC system to be lifted out of the past Cinderella state into the glory of a new community college future, it is nice to be able to quote the state's own verdict on the system rather than the musing of some hypercritical academic.

Here is the judgement, the Management report of the Auditor-General of South Africa on the performance audit of the Adult Education and Training Programme at the Department of Higher Education and Training for 2014 (Auditor-General, 2014, 2015), for the years 2011 and 2012.

- the concurrent (national and provincial) functions were not performed, partly because of budget inadequacies

- monitoring and evaluation visits were not done

- adult education and training operations in the provinces were not done

- the Department did not develop a strategy to deal with or track the extent of underqualified and unregistered educators (and in the years 2008 to 2011 audit checks on five provinces (which excluded Eastern Cape and Limpopo) that the percentages of unqualified educators in a province ranged from $4 \%$ to $47 \%$.)

- only two provinces had functioning Centre Governing Bodies and the Department did not know how many Centre Governing Boards were in place

- relations between the School Governing Bodies, principals and adult education centre officials, were poor at some centres

- there were challenges relating to facilities, security and resources

- there was no monitoring of the registering of private centres and no checking of the standards at private centres was done

- adequate support was not given to provinces

- the National Advisory Board for Adult Basic Education and Training was not set up

- there was poor liaison with the Kha Ri Gude adult literacy campaign to ensure that Kha Ri Gude learners could progress further

- little curriculum development took place between 2008 and 2014

- little support on materials was provided

- provincial EMIS data on such things as learner enrolment and educators per centre were released too late to be useful for operations and planning for either the current or the following year and neither the provinces nor the national department verified the data to ensure accuracy (and there were differences between EMIS data on learner numbers and Adult Education and Training data)

- there was no crucial management information data on such things as pass rates for ABET Levels 1 to 3, dropout rates, absenteeism rates, etc.

- teacher: learner ratios were below the 1:20 norm

- programme performance indicators could not be used because of lack of data

- an adult education and training framework was not developed 
- educators' conditions of service had not been standardised

- average costs per learners differed between provinces (e.g., in 2010-2011, KwaZuluNatal spent R3,431 per learner, and the Eastern Cape spent more than R8,500 per learner) and the costs excluding educator payments were even more diverse (Western Cape R5 per learner, Gauteng R1,152 per learner).

We sum up. The right to basic adult education has been disregarded and flouted. That right to basic education might have been "secured" in the constitution, but, to use wifi phraseology, there was "no connection." Nothing really changed and nothing was delivered.

\section{A minimal programme of reform}

This PALC system is only a pale shadow of what is needed as a South African adult and community education system, and really weak as the foundation of a future community college system that could really benefit the country. As the most minimal programme of reform, repairs and reforms that this foundation needed in the past decade, and still needs, are, as adequately described in the title of Brahm Fleisch's book, "the education triple cocktail” prescription for conventional schools (Fleisch, 2018).

\section{Materials}

This should be a priority. There must be serious curriculum and materials development. The Department of Basic Education proved it is possible to develop quality workbooks for all languages and mathematics for primary schools in less than six months and get them delivered to all schools, and a similar exercise needs to be undertaken for at least core formal courses to be offered in the Community College system.

\section{Scripted lesson plans}

These are clearly needed because so many untrained, poorly equipped teachers are working as educators in adult learning centres; shockingly, according to figures received in 2019 from DHET's EMIS system, 31\% (8,329 of 26,756) of educators employed nationally in 2017 had only a school leaving certificate.

\section{Supportive teacher training}

This needs to be done regularly, systematically, and, ideally, have elements of one-on-one teacher training.

In addition, for this programme of minimal improvement, the following components would also need to be funded.

\section{Salaries}

Those for educators and administrators would need to provide for more permanent, dedicated, adult education staff, and allow for considerable expansion of the FET component (Senior 
Certificate/NASCA). Coordinating and support staff at central Community College Administrative Centres, and the proto-community college nodes at district level that would each serve a cluster of nearby Community Learning Centres (the ex-PALCs).

\section{Support for training}

Universities and other providers of adult educator training need to reverse the disastrous dismantling of this capacity over the last decade and gear up for larger output and various forms of continuing in-service education for educators and administrators, especially for those educators who have only Grade 12. (Currently, as part of the its Teaching and Learning Development Capacity Improvement Programme, funded by the European Union, DHET is funding the development of qualifications for Community College educators in at least nine South African universities).

\section{Monitoring}

An effective EMIS system and a professional inspectorate are needed.

\section{Examinations}

Costs of the GETCA and Amended Senior certificate/NASCA examinations would need to be met.

These measures would ameliorate the most glaring weaknesses of the current ex-PALC system and cost only a fraction of what has been allocated by DHET to paying for the education of students at higher education institutions. Unless at least this triple cocktail is embraced it is pointless to have universities developing better Adult and Community Education qualifications for a system that continues to be dysfunctional and is disintegrating (with centres being supposedly consolidated, some have been closed down). This is because there will be no work for educators in the ex-PALC system if the rhetoric of community colleges floats high above this world.

\section{Towards a comprehensive programme of reform}

This rhetoric of community colleges arose from the White Paper for Post-school Education and Training (DHET, 2013) and the work of a Task Team established in 2011 (DHET, 2012a, 2012b) that envisaged an effective South African post-school or community education system seven years ago, and now, extremely encouragingly, finds expression in DHET's The Community Education and Training College System: National Plan for the Implementation of the White Paper for Post school Education and Training System 2019-2030 (DHET, 2019a). The White Paper saw the system playing a vital role in bringing educational opportunities to all, but particularly to those who had been poorly treated under apartheid. It envisaged enabling easy access to different types of learning at different levels to people in both rural and urban areas and affording people across the country learning opportunities related to their life contexts. In 2016, the Education, Training and Development Practices Sector Education 
and Training Authority (ETDP SETA) contracted the Adult and Community Education Unit of the Durban University of Technology to develop a discussion document on the model of community colleges that would be ideal for the South African context. This document, developed by the authors of this article (Land \& Aitchison, 2017), was discussed in various fora and modified in response to feedback from several quarters. The suggestions made in this document are embodied in the national plan for community colleges referred to above (DHET, 2019a). If this plan is implemented, we will have a truly transformed system that is not only secure but also connected, and, as such, possibly even has some hope of attracting the one million learners it targets for 2030.

The model suggested in the discussion document and the implementation plan differs vastly from minimal reform of PALCs and proposes (DHET, 2019a) that lecturers in the sector need capacity development and support, and that a capable and responsive quality assurance system is needed. It also proposes a curriculum designed to meet the current needs of the youth and adults that is delivered through a variety of delivery modes including open learning, and supported by the development and/or procurement of quality learning and teaching support materials, including Information and Communications Technologies-based materials. It also points to the great need for development, acquisition, and maintenance of appropriate infrastructure for community education programmes, suggests a robust student and community support service system, and capacity development of councils, management, and student leadership.

The discussion document on the ideal institutional model for community colleges in South Africa (Land \& Aitchison, 2017) makes similar recommendations and suggests that community colleges should offer an expansion of formal educational options that have been traditionally offered in PALCs to include ABET levels, GETCA, and NASCA, and a range of learning options to suit people at different stages of life, relating directly to the life circumstances of ordinary people, with a particular focus on safety and sustainable livelihoods. It strongly recommends access to the internet, and to information about accessible resources and different learning options. It envisages Community Learning centres (CLCs) as giving options for people to volunteer for a range of services, like, for example, homework clubs for young children overseen by volunteers who have passed Grade 12, and thus gain experience.

Non-formal learning options suggested in the discussion document include financial literacy; how to use cell phones, tablets, and the internet; voter education; health education; environmental education; conflict resolution; road safety; child care; sports for children as well as adults and pensioners from mini-soccer, mini-netball, and mini-cricket for young children through to soccer and keep fit classes for grandmothers and grandfathers; skills development for income generation; and training in recognising scams and fake news.

It suggests that CLCs be nodal point of access to communities where local, provincial, and national government departments, civil society organisations, businesses, and NGOs/community based organisations (CBOs) could cooperate and form alliances for the good of ordinary people, and to achieve collective goals. Learning spaces could 
accommodate community activities, possibly serving as venues for mobile clinics and mobile libraries. Crèche and preschool facilities at CLCs could enable learners to count on the safety of their children while they learn, give children the benefit of preschool learning activities, and give otherwise unemployed youth supervised practical training in ECD.

Both the implementation plan (DHET, 2019a) and the discussion document (Land \& Aitchison, 2017) point to the imperative for effective educator training and retraining if the old PALC system is to be transformed. The implementation plan (DHET, 2019a) advocates fit-for-purpose training to enable educators to deliver the diversity of programmes planned for Community Colleges. The discussion document notes the need for teaching staff to be well trained in order to be able to respond to people's needs, to access online material and adapt it to suit their learners, and to design educational events to achieve particular purposes. This training, and access to online material would bring huge relief to adult educators, especially those who bear the costs of providing material themselves (given the paucity of learning materials). The substantial investment by DHET in the development of Advanced Diplomas in Adult and Community Education and Training at many of our universities is a beacon of hope for the future against the bleak history of adult and community education in South Africa.

Initially, funding of a Community College system such as this might seem prohibitive. However, investment in education is investment in a nation's future, and the advantages of investing in this system are manifold. Even the brief sketch given above suggests that the model described in the implementation plan and the discussion document, with its access to the internet, would shed the stigma of old night schools and PALCs, and be an economical way of achieving various different goals of government since it would

- attract far greater numbers of learners, primarily because of the appealing attraction of internet access, but also because of the wider range of learning options;

- facilitate the planned rollout of ECD facilities across the country, thus ensuring that children whose caregivers attend have a better chance of succeeding at school;

- aid people's efforts to generate an income for themselves and secure their livelihoods; and

- offer cheaper and more efficient management than that of the old PALC system.

South Africa is not a poor country, and one cannot avoid the perception that the main obstacle in the way of the development of a truly comprehensive community college system is an entrenched apartheid style mind set which makes hopelessly inadequate learning options for ordinary people seem normal and acceptable. This mind set is shared, unfortunately, by most of us from learners through educators to DHET officials and planners, and it prevents our imagining and creating an effective adult and community education system. As a nation we are well known for having exceptionally good policies, but, sadly, also known for failing to implement them, and thus failing to benefit from the gains they offer. In this paper, we have tracked the history of our adult education system through its historical blunders and 
shortcomings and ended with a view of the far-reaching benefits inherent in government's new plan for the post school system (see DHET, 2019a).

Everyone involved in the post school system needs to distinguish, actively and consciously, between remembered past activities and what is possible now, especially given the National Plan for the Implementation of the White Paper for Post school Education and Training System 2019-2030 (DHET, 2019a), and translate the difference into action within our spheres. Without that, the system is doomed, and, as Santayana warned (1905), we will helplessly repeat the history of offering adult education as it was offered by the apartheid government, thus fulfilling Marx's (1852) description of history repeated as farce.

\section{References}

Aitchison, J. J. W. (2003a). Struggle and compromise: A history of South African adult education from 1960 to 2001. Journal of Education, 29, 125-178.

Aitchison, J. J. W. (2003b). Brak-vision, mirage and reality in the post apartheid globalisation of South African adult education and training. Journal of Education 31, 47-74.

Aitchison, J. J. W. (2004). Lifelong learning in South Africa: Dreams and delusions. International Journal of Lifelong Education, 23(6), 111-138.

Aitchison, J. J. W. (2013, November). Adult education and ABET policy, implementation plans, and research since 1992. Paper presented to the Centre for Adult Education, University of KwaZulu-Natal, Pietermaritzburg, RSA.

Aitchison, J. J. W. (2016). Proxies and perplexities: What is the current state of adult (il)literacy in South Africa? Journal of Education 66, 47-74.

Aitchison, J. J. W., \& Harley, A. (2006). South African illiteracy statistics and the case of the magically growing number of literacy and ABET learners. Journal of Education, 39, 89-112.

Aitchison, J. J. W., Houghton, T., \& Baatjes, I. (2000). University of Natal survey of adult basic education and training: South Africa. Pietermaritzburg: Centre for Adult Education, University of Natal.

Auditor-General of South Africa. (2014). Management report of the Auditor-General of South Africa on the performance audit of the Adult Education and Training Programme at the Department of Higher Education and Training. Pretoria, RSA: Author. 
Auditor-General of South Africa. (2015). Discussion extract of the management report of the Auditor-General of South Africa on the performance audit of the Adult Education and Training Programme at the Department of Higher Education and Training. Pretoria, RSA: Author.

Department of Education. (1995). A national adult basic education and training framework: Interim guidelines. Pretoria, RSA: Author.

Department of Education. (1997a). Policy document on adult basic education and training: October 1997. Pretoria, RSA: Author.

Department of Education. (1997b). A national multi-year implementation plan for adult education and training: Provision and accreditation. October 1997. Pretoria, RSA: Author.

Department of Education. (2000). Draft ABET sectoral report. Pretoria, RSA: Author.

Department of Education. (2001). Building an ABET system: The first five years 1995-2000. Pretoria, RSA: Author.

Department of Education. (2003). Education statistics in South Africa at a glance in 2001. Pretoria, RSA: Author.

Department of Education. (2004). Education statistics in South Africa at a glance in 2002. Pretoria, RSA: Author.

Department of Higher Education and Training. (2012a). Report of the task team on community education and training centres. Pretoria, RSA: Author.

Department of Higher Education and Training. (2012b). Report of the task team on community education and training centres: Summary. Pretoria, RSA: Author.

Department of Higher Education and Training. (2013). White Paper for Post-School Education and Training. Pretoria, RSA: Author.

Department of Higher Education and Training. (2014). Statistics on post-school education and training in South Africa: 2012. Pretoria, RSA: Author.

Department of Higher Education and Training. (2017a). Ministerial committee on the review of the funding frameworks of TVET colleges and CET colleges: Information report and Appendices. Pretoria, RSA: Author.

Department of Higher Education and Training. (2017b). Statistics on post-school education and training in South Africa 2016. Pretoria, RSA: Author. 
Department of Higher Education and Training. (2019). The Community Education and Training College System: national plan for the implementation of the White Paper for Post school Education and Training System 2019-2030. Pretoria, RSA: Author.

Fleisch, B. (2018). The education triple cocktail: System-wide instructional reform in South Africa. Cape Town, RSA: Juta.

Harley, A., Aitchison, J., Lyster E., Land S., with Fotheringham, R., Hallowes, D., . . . Tuchten, G. (1996). A survey of adult basic education in the South Africa in the 90s. Johannesburg, RSA: SACHED Books.

Howie, S. J., Combrinck, C., Roux, K., Tshele, M., Mokoena, G. M., \& McLeod Palane, N. (2017). PIRLS literacy: 2016 South African highlights report. Pretoria, RSA: Centre for Evaluation and Assessment, Faculty of Education, University of Pretoria.

Human Sciences Research Council. (2000). Annual survey of public adult learning centres 1999: Final report. Pretoria, RSA: Author.

Land, S. \& Aitchison, J. J. W. (2017). The ideal institutional model for community colleges in South Africa: A discussion document. Durban, RSA: Adult and Community Education Unit, Durban University of Technology.

Marx, K. (1852). The eighteenth brumaire of Louis Napoleon. Retrieved from https://www.marxists.org/archive/marx/works/1852/18th-brumaire/ch01.htm

Ministerial Committee on Literacy. (2007). Plan for a mass literacy campaign for South Africa: Summary. Pretoria, RSA: Department of Education.

National Education Policy Investigation. (1992). Adult basic education: Report of the Adult Basic Education Research Group. Cape Town, RSA: Oxford University Press.

National Training Board. (1991). National training strategy initiative: Draft report. Pretoria, RSA: Author.

National Training Board. (1994). National training strategy initiative. Pretoria, RSA: Author.

Santayana, G. (1905). The life of reason: Reason in common sense. New York, NY:

Scribner's. 